\title{
Design and simulation of a mechanical system for the machining of parts and printing in 3D $(\mathbf{x}, \mathbf{y}, \mathbf{z})$ Diseño y simulación de un sistema mecánico para el mecanizado de piezas e impresión en 3D $(\mathbf{x}, \mathbf{y}, \mathbf{z})$
}

\author{
Luis Miranda-Molina ${ }^{1 a}$, Asdrubal Quinayas-Ortiz ${ }^{\text {1b }}$, Gabriel Peña-Rodríguez ${ }^{2}$ \\ ${ }^{1}$ Department of Electricity and Electronics, Universidad Francisco de Paula de Santander, Colombia. \\ Orcid: ${ }^{\mathrm{a}}$ 0000-0001-9335-0218, ${ }^{\mathrm{b}} 0000-0002-1176-7536$. \\ Emails: aluisantoniomm@ufps.edu.co, asdrubalquinayas@gmail.com \\ ${ }^{2}$ GIFIMAC Research Group, Universidad Francisco de Paula de Santander, Colombia. \\ Orcid: 0000-0002-7114-9174. Email: gabrielpr@ufps.edu.co
}

Received: 3 February 2020. Accepted: 28 May 2020. Final version: 26 July 2020.

\begin{abstract}
The design and simulation of a multifunctional system for the machining of mechanical parts and printing in 3D (x, y, z) using CAD software Solid works, was used to determine the static behavior of the system with the analysis of tension, deformation, displacement, safety factor, buckling, fatigue and frequency. For the above, it was determined that the lateral base supports a tension of $3.5 \times 10^{8} \mathrm{~Pa}$, causing a displacement of $25 \mathrm{~mm}$ and an equivalent unit strain (ESTRN) of 0.0012. And the base guiding a cumulative damage of $300 \%$ of deterioration that reduces its useful life to a range between $1 \times 10^{6}$ and $1 \times 10^{65}$ utility cycles and a safety factor (F S) between 104.632 to 7869.86 . On the other hand, the transverse base has a maximum cumulative damage percentage of 4.10535 and a life cycle range ranging from 24358.5 to $1 \times 10^{6}$ with a minimum SF of 5974 .
\end{abstract}

Keywords: CNC; module; design; solidworks; machine.

\section{Resumen}

El diseño y la simulación de un sistema multifuncional para el mecanizado de piezas mecánicas y la impresión en 3D $(\mathrm{x}, \mathrm{y}, \mathrm{z})$ utilizando el software CAD Solid works, se utilizó para determinar el comportamiento estático del sistema con el análisis de tensión, deformación, desplazamiento, factor de seguridad, pandeo, fatiga y frecuencia. Para lo anterior, se determinó que la base lateral soporta una tensión de $3.5 \times 10^{8} \mathrm{~Pa}$, causando un desplazamiento de $25 \mathrm{~mm}$ y una tensión unitaria equivalente (ESTRN) de 0.0012. La base guía un daño acumulado del $300 \%$ del deterioro, reduce su vida útil a un rango entre 1x106 y 1x1065 ciclos de utilidad y un factor de seguridad (F S) entre 104.632 a 7869.86. Por otro lado, la base transversal tiene un porcentaje de daño acumulado máximo de 4.10535 y un rango de ciclo de vida que varía de 24358.5 a 1x106 con un SF mínimo de 5974.

Palabras clave: módulo; diseño; solidworks; máquina.

ISSN Printed: 1657 - 4583, ISSN Online: 2145 - 8456, CC BY-ND 4.0 (c) (1) $\odot$

How to cite: L. Miranda-Molina, A. Quinayas-Ortiz, G. Peña-Rodríguez, "Design and simulation of a mechanical system for the machining of parts and printing in 3D (x, y, z)," Rev. UIS Ing., vol. 19, no. 4, pp. 115-122, 2020, doi: https://doi.org/10.18273/revuin.v19n4-2020010 


\section{Introduction}

Thanks to the development and innovation of new technologies, the automation of industrial processes over time has led to significant advances that have allowed companies to implement more efficient, safe and competitive production processes. Due to this, the machine components are increasingly imposed in the Industrial field, so the complexity requirements of the parts that are required, are developed by numerical control systems to improve the position regulation in all axes and optimize its precision and speed in order to develop more efficient industrial processes. In fact, at present, different techniques and methods such as: triangular mesh measurement [1], minimum zone methods in computational geometry [2], laser scanning techniques [3] and dimensional and three-dimensional wavelet transform method [4].

Also, the machining processes and creation of mechanical parts use two strategies of initiation that requires the intervention of a user only by establishing the initial position of the milling tool, while in the second it allows to prescribe a preferable route tool [5]. Solid works software was used to analyze the static construction, displacement and deformation of the system, which has made it possible to verify that one of the most common problems in the modules is the work of retaining the different materials of the pieces and shapes during the machining operation, as well as their limitations of operation [6], since some of them only perform one machining process at a time, which increases the production time.

Due to the above, the design of a multifunctional system, fast and precise, using the "Solidworks Simulations" tool of Solidworks CAD software, is presented in order to know its mechanical properties and its static behavior through the different analysis of tension, displacement, deformation, fatigue, buckling and frequency.

\section{Materials and methods}

For the construction of the design was used a VAIO processor that has: an Intel $(\mathrm{R})$ Pentium $(\mathrm{R})$ processor inside, CPU B940 $2.00 \mathrm{GHz}$, RAM of $4.00 \mathrm{GHz}$, and 64bit operating system, in which the design of the pieces was done using the research method for static linear construction, displacement and deformation of the system based on "Static structural analysis of the large CNC five-axis CNC turning" [7] using CAD software SOLIDWORK 2015 [8], where the pieces were molded and inserted into an assembly by position relationships. This software was selected for its design, simulation technology, animation details, visual instructions and user-friendly interface for the design.

The development of the pieces that make up the mechanical structure, was based on the operation of the positioning machines $\mathrm{X}, \mathrm{Y}, \mathrm{Z}$ considering the following parameters:

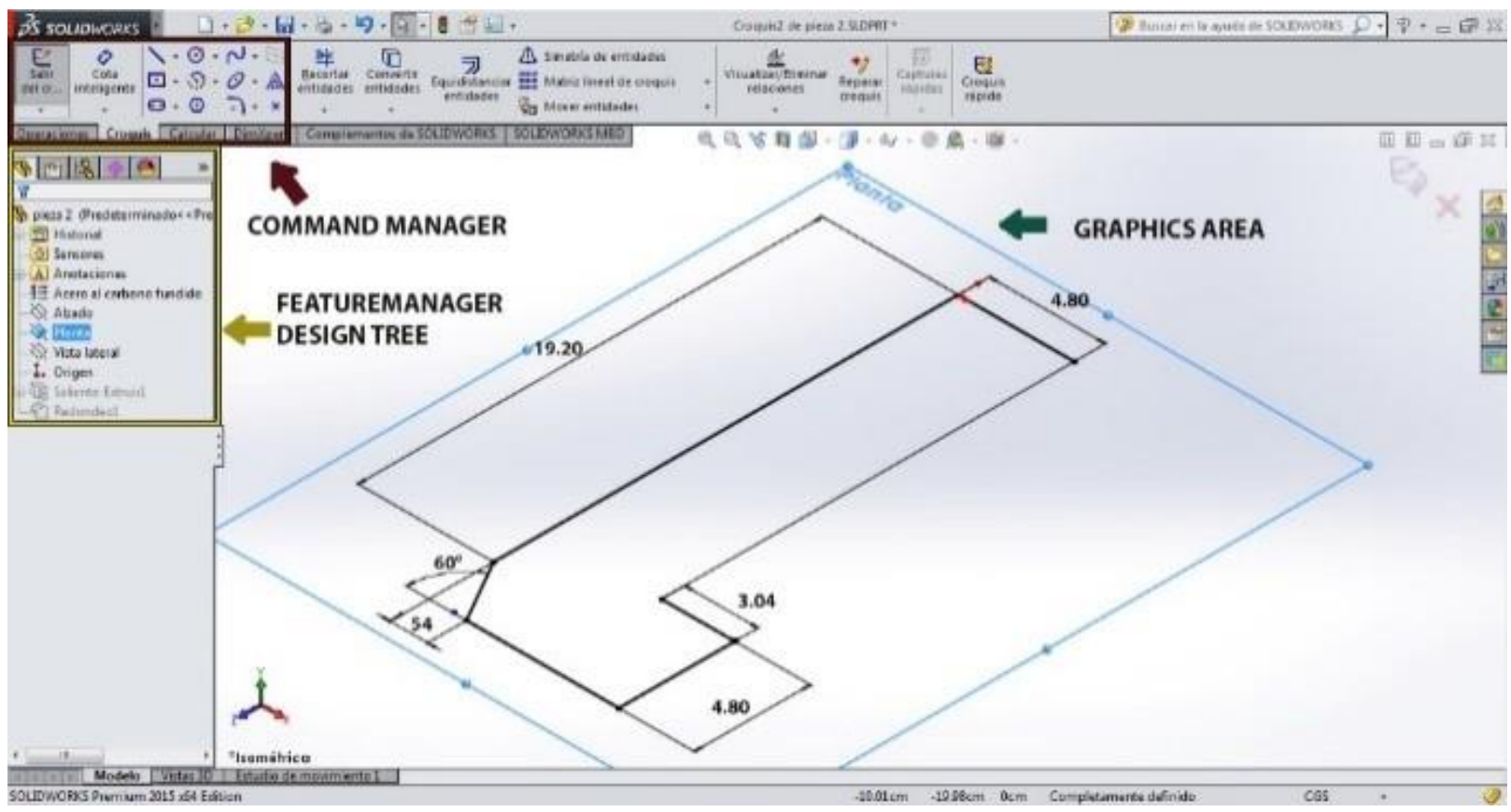

Figure 1. Solidworks design interface. 
weight, inertial points, center of mass, mechanical strength of ball screws and spindles, normal stresses, safety factor, welding points, mechanical vibrations and movement performed by the structure. For the stepper motors, the worm screws, the spindles, the guide line, the anti-vibrator and levelers, the CAD of the original manufacturers was unloaded to assemble them.

In other words, each piece was made using a new document in the graphics area where the measurement system was selected through the "document properties" option. Next, in the design manager, the "plant" plane was selected to start the design of the pieces that make up the $3 \mathrm{D}$ positioning system. Some of them can be seen in Table 1 along with its design process, dimensions and physical properties. For the elaboration of these pieces the design tools (line, center icon, trim entities and collate, among others) located in the "Command Manager", by means of which the initial sketch of the piece was molded, are used fixed in the measurements, then entered in the tab of operations and the tool "extrude outgoing base" of the administrator's command was used, in which a specific depth of $0.9 \mathrm{~cm}$ in "D1" was established to give volume to our design. Figure 1, an exception of the table that was designed through the tool "3D sketch", where its geometry was drawn by means of a set of lines and dimensions, followed by the insertion of the square structural tube of $40 \times 40 \times 5 \mathrm{~mm}$ by the tool "structural member" of "welded parts" Table 1. Carbon-fused steel was then selected in the "function manager" for its high mechanical strength, great marketing and low cost [9].

The physical properties of the parts were then determined using the "calculate" tool of the Command Manager, where its density, mass, volume, surface area and center of mass were observed to determine the weight of the parts of the assembly depending on their position. Table 1. Subsequently, the "position relationship" tool (matching, parallel, perpendicular, tangent and concentric), "advanced position relationships" and "weld bead" was performed by the solder technique. Welding fill [10], which is observed in Table 2 by a block distribution, where the upper structure of the system represents the axis ZY (block A), and is placed on the lower structure (block $\mathrm{B}$ ) representing the $\mathrm{X}$ axis, to finally obtain the mechanical system (block $C$ ) and to be able to generate the representative 1: 5 scale based on the DIM standard [11] (block D).

Then, to observe the static behavior of the system, different simulation tests were carried out on the main pieces using the "Solidworks simulation", using the "von Mises Voltage" method, based on TH LIN and M. IT0 in his article "Theoretical plastic stress-strain relationship of a polycrystal and the comparisons with the Mises and the Tresca plasticity theories "[12].

First the static analysis was executed in the "create study" tab of Simulation of the Property Manager, then the restrictions were defined in the "Fixtures" icon of the "Simulation" manager "fixed geometry", which is the most suitable to stabilize the arm lateral (piece 1) through contact conditions, then a uniform vertical and horizontal external load of $10 \mathrm{~kg}$ was exerted on the piece, a meshing of triangular elements was generated by the mesh option of the Property Manager where a density was selected of fine mesh that allowed to calculate the internal, external, deformations, displacement and safety factor loads based on the method of analysis of "finite elements" (FEA) or "computer aided design" [13] in which the results of Figure 2 were obtained.

A new fatigue study was then made and the load type was set in "Find Cycle Peaks" where the SN curve for each material was added by clicking on "SN fatigue curves" in the "Material" dialog box, and we performed Figure 2, to observe if the repetition or randomness causes a structural error (also called metal fatigue), as determined by Juan Luis Hernández Arellano PhD, in his article "Structural equation models applied to the analysis of fatigue"[14].

We then calculated the critical failure loads of the thin structures under the effects of a compression to predict possible failure modes, as did A. May-Pat and F. Avilés in "Numerical analysis of interfacial fracture in sandwich columns subjected to compression axial "in which a non-linear geometric Analysis was performed by the finite element method carried out to predict the fracture parameters [15], then the properties were defined to establish the number of modes and their restrictions by "Load / Restrictions" in the "Simulation" manager, then the model was stabilized and executed resulting in the buckling graph of Figure 2.

The natural frequencies of the piece were then calculated to predict possible failure modes, to better understand its performance and to verify if a harmonic resonance occurred in the piece, through a new study in which "frequency study (EDF) "Selecting" automatic solver "for any defects, then the material, fasteners, loads, meshed and executed the analysis showing the behavior of the piece in its different frequencies Figure 2. 


\section{Results and discussion}

In Table 3.0 we can see the direct relationship between the affected areas of the pieces and the magnitude of the obtained results, which are classified by an upward colored bar Figure 2. It is also observed that the tension exerted on the lateral base significantly exceeds the stresses on the other parts, which causes a deformation in its center due to the involuntary displacement that is generated Figure 3. Therefore, it is recommended to change the material, to modify the geometry of the superior structure or to reinforce the base lateral with support pillars that isolate the lateral base of the table by means of a membrane of natural rubber to diminish the mechanical vibrations and to avoid that the structures enter resonance. It is also observed that the transverse base has a high range of F.S. On the contrary, the guiding base has an accumulated higher damage, which decreases its life cycles and increases its permanent elastic deformation (buckling) Figure 3. It was also determined by the frequency analysis that the pieces do not enter into natural resonance with a directly proportional growth between them as observed in Figure 4, elaborated by MATLAB software [16].

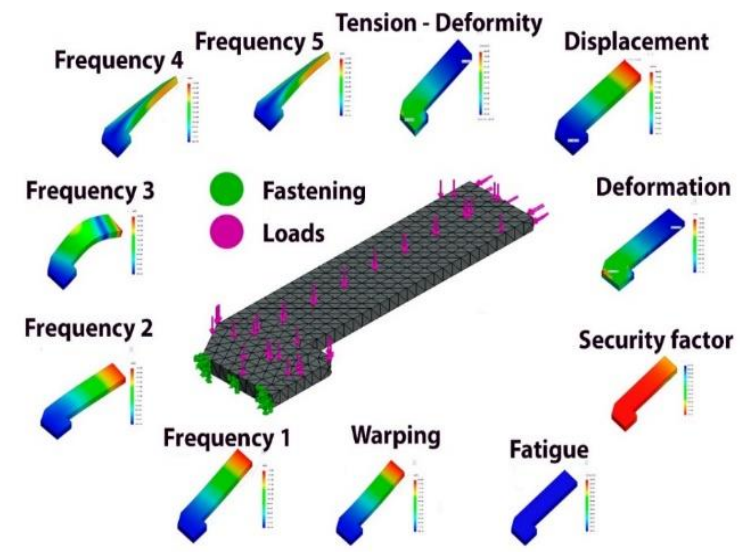

Figure 2. Lateral arm results (piece 1) in Solidworks simulations.

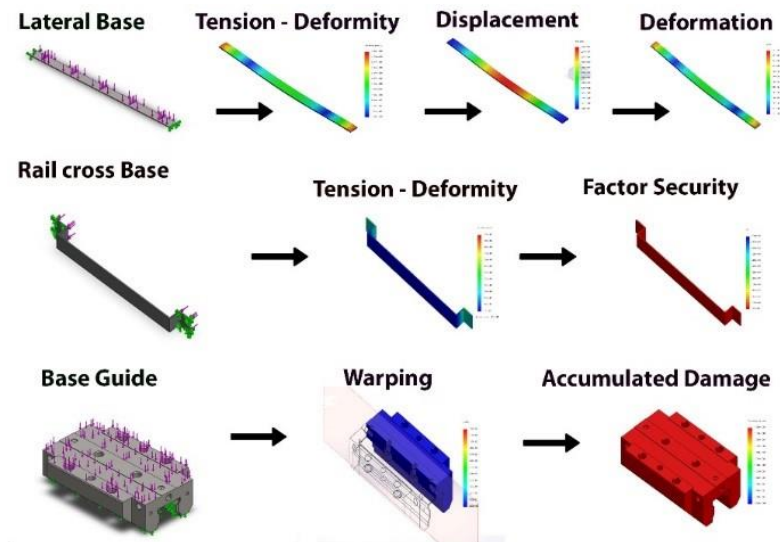

Figure 3. Results of side base, cross base, guide base.

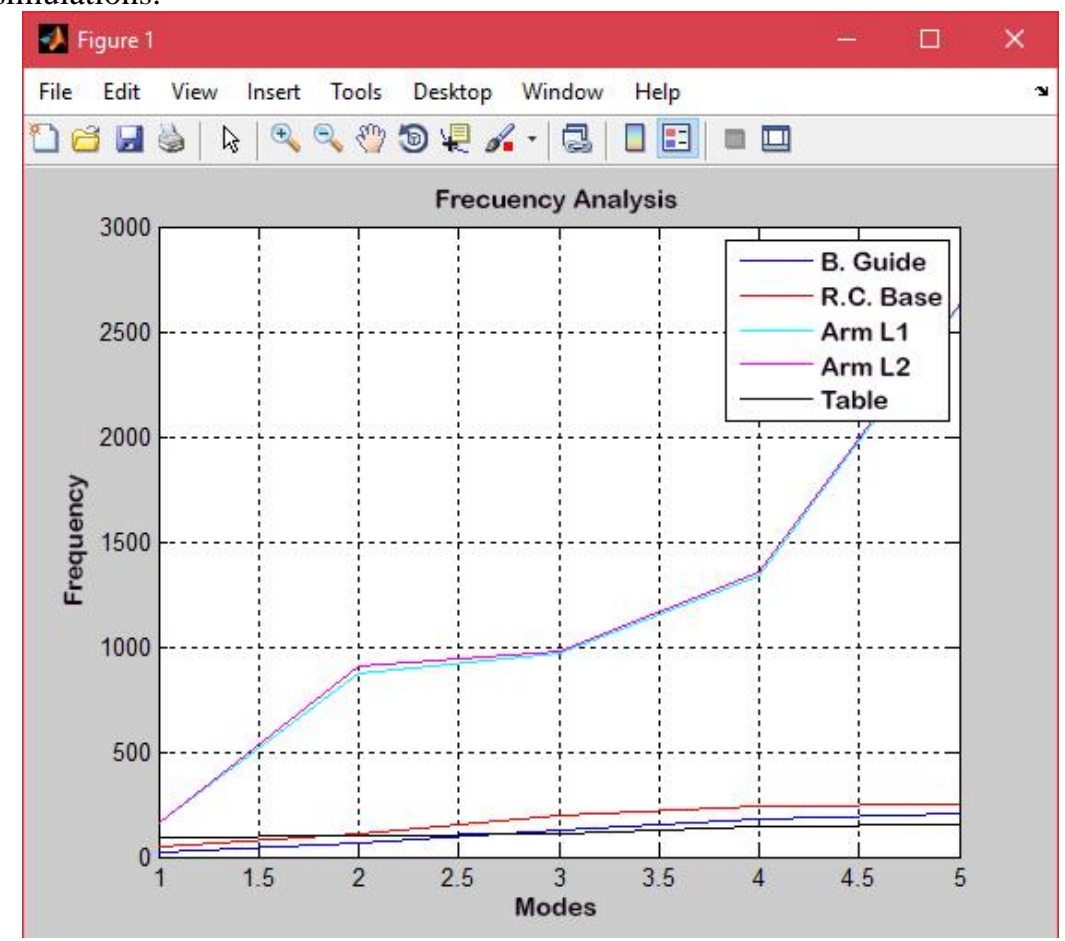

Figure 4. General graphics of frequency study. 
These results were determined using the finite element analysis method (FEA) using the solid works software, where displacement and deformation were formulated through normal stresses, unlike the study formulated by displacements and exact nodal solution of deformed columns by shear stress according to Timoshenko's theory based on the concept of "Equivalent Distributed Action" (AER) [17] or the method to obtain the Effort Intensity Factor (FIS) using the Integral of Interaction coupled to the Element Method Extended Finite Finishing (MEFX) [18].

Table 1. Design process

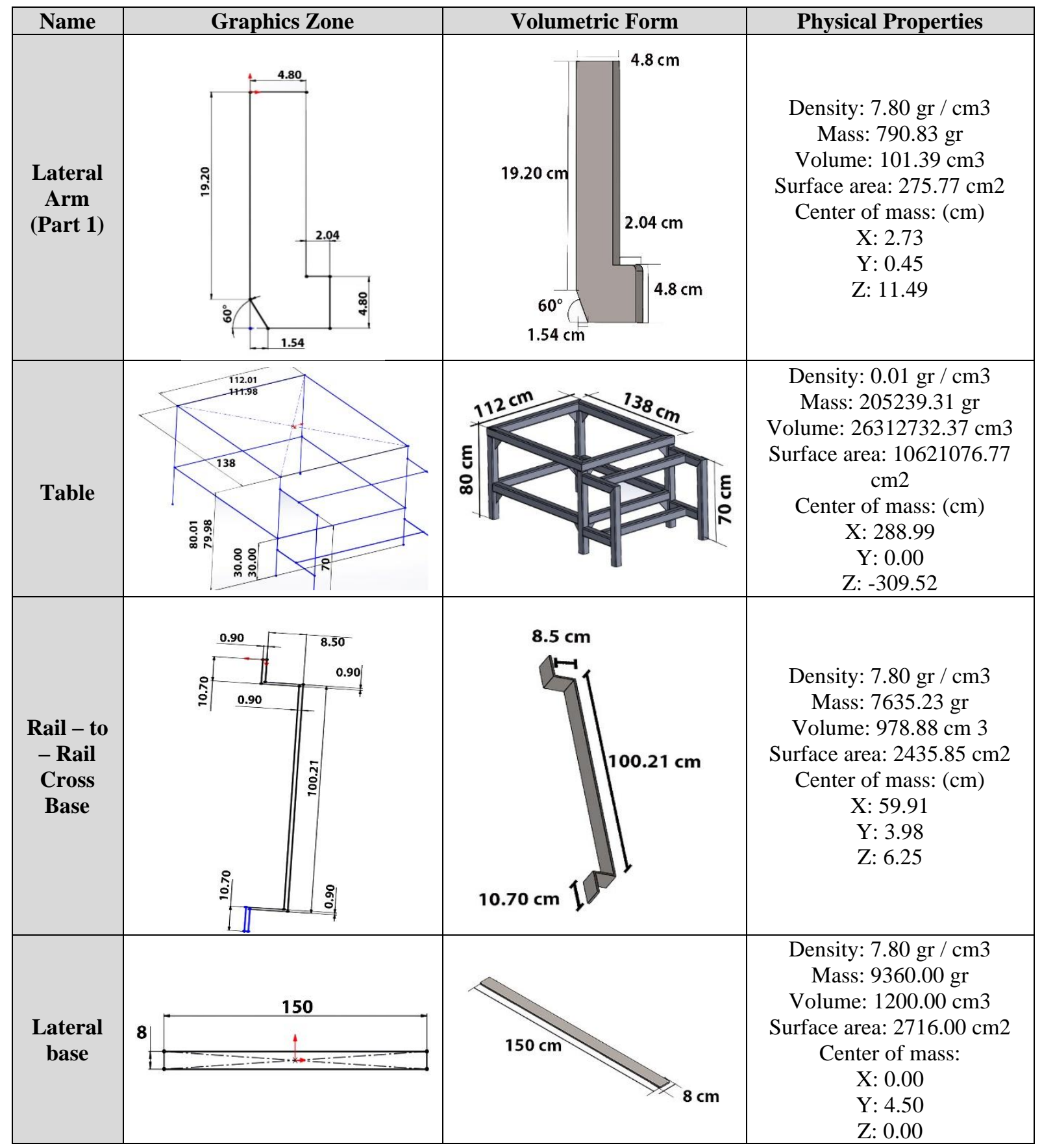


Table 2. Assembly of the system

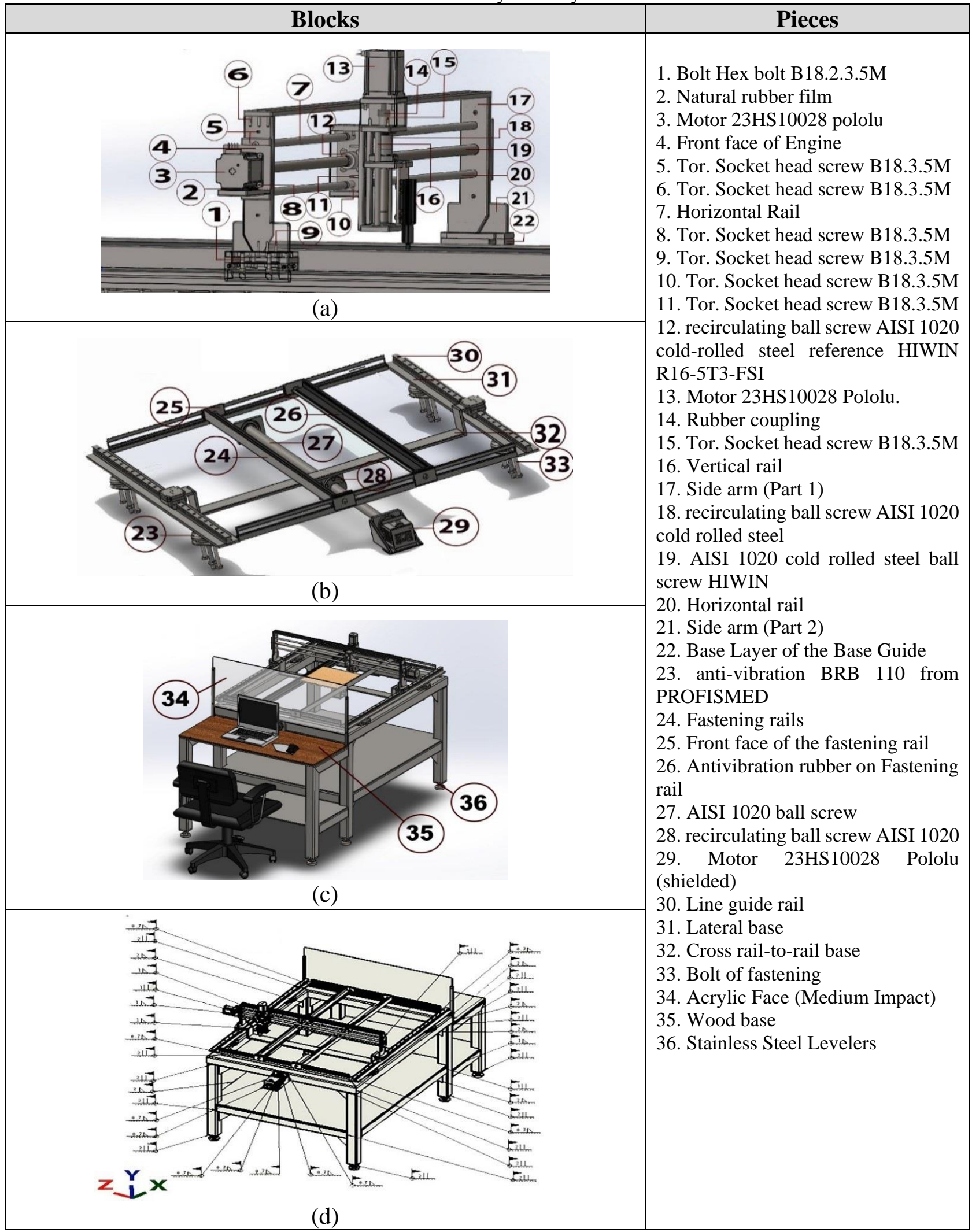


Table 3. Results

\begin{tabular}{|c|c|c|c|c|c|c|c|}
\hline \multicolumn{2}{|l|}{ Analysis } & Guide base & $\begin{array}{c}\text { Transverse } \\
\text { base from riel } \\
\text { to riel }\end{array}$ & $\begin{array}{l}\text { Lateral arm } \\
\text { (piece 1) }\end{array}$ & $\begin{array}{l}\text { Lateral arm } \\
\text { (piece 2) }\end{array}$ & Table & Side base \\
\hline \multirow{2}{*}{ Tension $\left(\mathbf{n} / \mathbf{m}^{2}\right)$} & Maximum & 2.37181 & 41541.4 & $1.3164 \times 10^{6}$ & 959773 & $2.4505 \times 10^{7}$ & $3.44585 \times 10^{8}$ \\
\hline & Minimum & 31534 & 0.00255204 & 1580.15 & 753.661 & 43468.2 & 12836.7 \\
\hline \multirow{2}{*}{ Displacement(mm) } & Maximum & 0.000250588 & $4.47783 \times 10^{5}$ & 0.000496074 & 0.000464182 & 0.241988 & 24.8569 \\
\hline & Minimum & 0 & 0 & 0 & 0 & 0 & 0 \\
\hline \multirow{2}{*}{ Deformation (estrn) } & Maximum & $7.32437 \times 10^{6}$ & $1.6233 \times 10^{7}$ & $4.19614 \times 10^{6}$ & $3.93245 \times 10^{6}$ & $3.47845 \times 10^{6}$ & 0.00117746 \\
\hline & Minimum & $1.47475 \times 10^{7}$ & $1.00553 \times 10^{12}$ & $9.85864 \times 10^{9}$ & $1.26869 \times 10^{8}$ & $1.23459 \times 10^{8}$ & $7.5215 \times 10^{8}$ \\
\hline \multirow{2}{*}{ Security factor } & Maximum & 7869.86 & $9.72429 \times 10^{10}$ & 157053 & 329284 & 5709.18 & 19332.7 \\
\hline & Minimum & 104.632 & 5974 & 188.52 & 258.569 & 10.1272 & 0.720195 \\
\hline \multirow{3}{*}{$\begin{array}{l}\text { Buckling ampres (plot } \\
\text { resultant plot for } \\
\text { modal) }\end{array}$} & $\begin{array}{l}\text { Maximum } \\
\text { amplitude }\end{array}$ & 0.014505 & 0.0155143 & 0.0422935 & 0.0421425 & 0.00876118 & 0.008584 \\
\hline & $\begin{array}{l}\text { Minimum } \\
\text { amplitude }\end{array}$ & 0 & 0 & 0 & 0 & 0 & 0 \\
\hline & Factor - load & $1.843 \times 10^{5}$ & 46591 & 329.42 & 337.13 & 954.14 & 292.64 \\
\hline \multirow{4}{*}{ Fatigue } & $\begin{array}{l}\text { Accumulate } \\
\text { damage } \\
\text { maximum }\end{array}$ & $300 \%$ & $4.10535 \%$ & $0.1 \%$ & $0.2 \%$ & $80 \%$ & $4.10535 \%$ \\
\hline & $\begin{array}{c}\text { Accumulated } \\
\text { damage } \\
\text { minimum } \\
\end{array}$ & $0 \%$ & $0.1 \%$ & $0.1 \%$ & $0.2 \%$ & $0.1 \%$ & $0.1 \%$ \\
\hline & $\begin{array}{l}\text { Maximum total } \\
\text { life }\end{array}$ & $1 \times 10^{6}$ & $1 \mathrm{ex} 10^{6}$ & $1 \times 10^{6}$ & $1 \times 10^{6}$ & $1 \times 10^{6}$ & $1 \times 10^{6}$ \\
\hline & $\begin{array}{c}\text { Minimum total } \\
\text { life } \\
\text { (number of } \\
\text { cycles) }\end{array}$ & $1 \times 10^{6}$ & 24358.5 & $1 \times 10^{6}$ & $1 \times 10^{6}$ & $1 \times 10^{6}$ & 24358.5 \\
\hline \multirow{5}{*}{ Frequency (hertz) } & Frequency 1 & 26285 & 44.993 & 162.33 & 165.68 & 88.931 & 23.309 \\
\hline & Frequency. 2 & 29034 & 105.81 & 870.74 & 906.73 & 105.04 & 64.233 \\
\hline & Frequency. 3 & 29520 & 194.08 & 968.69 & 979.04 & 112.79 & 125.89 \\
\hline & Frequency. 4 & 31765 & 244.13 & 244.13 & 244.13 & 244.13 & 244.13 \\
\hline & Frequency. 5 & 32207 & 32207 & 32207 & 32207 & 32207 & 32207 \\
\hline
\end{tabular}

\section{Conclusions}

It was determined that due to the versatility of the module it is possible to make future adaptations in the axis and thus to implement different machining tools for different processes (cutting, drilling, milling, and 3D printing), it was also observed that the displacement and the deformation generated are directly proportional to the applied external force (i.e, Hooke's law of elasticity [19]), and inversely proportional to the magnitude of the physical properties of the material, whereby the safety factor depends on the magnitude of the force exerted on them, their fastenings, their geometrical shape and the mechanical properties of the material.

It was verified that the normal stress applied in the center of the pieces that are only subject at the ends generates a greater deformation in a shorter time, which varies according to its position and functionality, additionally it was found that the pieces made in aluminum or aluminum alloy have a greater permissiveness to mechanical vibrations, unlike steel, which adsorbs much of them preventing them from altering the overall operation of the system.

\section{References}

[1] A. Görög, S. Lakota, "Flatness measurement by Multi-point methods and by scanning methods," $J$ of Interdisciplinary Research, Slovak University of Technology in Bratislava, pp. 1-4, 2018.

[2] R. Raghunandan, P. Venkateswara Rao, "Selection of sampling points for accurate evaluation of flatness error using coordinate measuring machine," J. Mater. Process. Technol., vol. 202, no. 1-3, pp. 240-245, 2008, doi: 10.1016/j.jmatprotec.2007.09.066

[3] F. Bosché, E. Guenet, "Automating surface flatness control using terrestrial laser scanning and building information models," Autom. Constr., vol. 44, pp. 212226, Aug. 2014, doi: 10.1016/j.autcon.2014.03.028 
[4] W. Makiela, K Stepien, "Evaluation of flatness profiles by means of Wavelet Transformation," Faculty of Manuf Tech Tuke, Manuf. and Ind. Eng., vol. 11, no. $2,2012$.

[5] P. Bo, M. Bartoň, D. Plakhotnik, H. Pottmann, "Towards efficient 5-axis flank CNC machining of freeform surfaces via fitting envelopes of surfaces of revolution," Comput. Des., vol. 79, pp. 1-11, 2016, doi: 10.1016/j.cad.2016.04.004

[6] B. I. Oladapo et al., "Experimental analytical design of CNC machine tool SCFC based on electro-pneumatic system simulation," Eng. Sci. Technol. an Int. J., vol. 19, no. 4, pp. 1958-1965, 2016, doi: 10.1016/j.jestch.2016.08.010

[7] C. C. Hong, C.-L. Chang, C.-Y. Lin, "Static structural analysis of great five-axis turning-milling complex CNC machine," Eng. Sci. Technol. an Int. J., vol. 19, no. 4, pp. 1971-1984, 2016, doi: 10.1016/j.jestch.2016.07.013

[8] S. Gómez González, El gran libro de solidworks Edición 1. Marcombo S.A, México: Ed. Alfaomega, 2007.

[9] G. Valencia, Estructuras de acero. Diseño con factores de carga y de resistencia, edición 1. Colombia: Escuela Colombiana de Ingeniería, 1997.

[10] S. Segovia, Manual de soldadura. Ejercicios prácticos de soldadura al arco. Electrodo revestido, edición 1, 2012.

[11] I. Jiménez Mesa, J. Diaz-Tendero, J. Suárez Rivero, Dibujo Industrial. Manual De Apoyo Y Docencia, Océano, 20 de septiembre, 2014

[12] T. H. Lin, M. Ito, "Theoretical plastic stressstrain relationship of a polycrystal and the comparisons with the von Mises and the Tresca plasticity theories," Int. J. Eng. Sci., vol. 4, no. 5, pp. 543-561, 1966, doi: 10.1016/0020-7225(66)90015-2

[13] O. Rojas Lazo, L. Rojas Rojas," Diseño asistido por computador," Industrial Data, vol. 9, no. 1, pp. 7-15, 2006.

[14] K. S. R. Chandran, "A physical model and constitutive equations for complete characterization of SN fatigue behavior of metals," Acta Mater., vol. 121, pp. 85-103, 2016, doi: 10.1016/j.actamat.2016.09.001

[15] A. May-Pat, F. Avilés, “Análisis numérico de fractura interfacial en columnas sándwich sometidas a compresión axial," Ingeniería, vol. 11, no. 3, pp. 21-32, 2007.

[16] “Matlab”, MathWorks, 2016

[17] J. L. Romero, E. M. López, M. A. Ortega, O. Río, "Análisis de pilares con deformación por cortante mediante elementos finitos y acciones repartidas equivalentes," Rev. Int. Métodos Numéricos para Cálculo y Diseño en Ing., vol. 33, no. 3-4, pp. 280-289, 2017, doi: 10.1016/j.rimni.2016.06.002

[18] A. Sáenz López, “Análisis del factor de intensidad de esfuerzo utilizando el método de los elementos finitos extendidos," Revista de Arquitectura e Ingeniería, vol. 7, no. 1, pp. 1-11, 2013.

[19] H. Mao, R. Rumpler, P. Göransson. "An inverse method for characterisation of the static elastic Hooke's tensors of solid frame of anisotropic open-cell material," International Journal of Engineering Science, vol. 147, pp. 1-18, 2020, doi: 10.1016/j.ijengsci.2019.103198 